\title{
Giant axillary fibroadenoma: a rare case report
}

\begin{abstract}
Axillary ectopic breast tissue occurs commonly in women. The fibroadenoma is commonest benign tumour of the normal female breast. But fibroadenoma occurring in axillary ectopic breast tissue is of rare occurrence. The giant fibroadenoma are very rare in axillary ectopic breast tissue. This case is being reported having a giant fibroadenoma of $11 \times 10 \mathrm{~cm}$ in right axilla in 38 years female. The clinical history did not give any clue to presence of ectopic breast tissue in axilla. Excision biopsy confirmed the diagnosis of fibroadenoma. This case is being reported as giant fibroadenoma of such a large size occurring in axilla for its rarity.
\end{abstract}

Volume 7 Issue 2 - 2017

\author{
Bhavinder K Arora \\ Department of Surgery, Pt BD Sharma PGIMS, Rohtak, India
}

Correspondence: Bhavinder K Arora, Department of Surgery, Pt BD Sharma PGIMS, India, Tel +9l-9466290707

Email drbhavinderarora@gmail.com

Received: July 28, 2017 | Published: August 16, 2017

Keywords: fibroadenoma, giant fibroadenoma, axillary breast, ectopic breast tissue

\section{Introduction}

Fibroadenoma is commonest breast lump constituting about $50 \%$ of all breast pathologies in young females. About $2-4 \%$ of the fibroadenomas more than $5 \mathrm{~cm}$ in size or $500 \mathrm{gm}$ in weight and are called giant fibroadenomas. ${ }^{1}$ The axillary ectopic breast tissue is common in women as $95 \%$ of women are having it. ${ }^{2}$ The clinical presentation is during lactation when this tissue gets enlarged commonly called as axillary breast. ${ }^{3}$ This axillary breast tissue is affected by the hormonal status of woman as the normal breast tissue gets. This axillary breast tissue can develop the diseases similar to normal breast. The development of benign pathology like fibroadenoma has been reported in this axillary ectopic breast tissue occasionally. ${ }^{4}$ Other benign disorder like duct ectasia has also been reported. ${ }^{5}$ Even development of carcinoma has been reported in axillary breast tissue. ${ }^{6}$ Such large size lumps in breast need to be differentiated from phylloid tumours and axillary lymphadenopathy. ${ }^{7}$ Isolated case reports of fibroadenoma in axillary ectopic breast tissue are available in surgical literature [a reference]. These occasional case reports of fibroadenoma occurring in axilla have a small size but giant fibroadenoma with a large size of more than $5 \mathrm{~cm}$ has been reported once only. ${ }^{8}$ We present another case report of giant fibroadenoma occurring in axilla in a non lactating woman with very large dimensions. This case report includes clinical, operative and pathological images.

\section{Case report}

A thirty eight years female presented with a large swelling in right axilla for last two years. This patient had history of a small swelling in this site for many years but this swelling has achieved large size in past two years. She was having three children and was perimenopausal. On palpation this axillary swelling was firm and freely mobile (Figure 1). A clinical diagnosis of large axillary breast was made. Clinical examination of bilateral breasts was normal. There was no ectopic breast tissue in left axilla clinically. In outdoor she was advised ultrasound of both breast and right axillary swelling. The ultrasonologist reported that bilateral breasts were normal and right axillary swelling was reported as axillary breast. Fine needle aspiration cytology was done to make tissue diagnosis and reported as ectopic breast tissue. This right axillary swelling was producing hindrance in wearing dress excision was planned. Haematological investigations were done; Haemoglobin- $12 \mathrm{gm} \%$, Total leucocyte count-9000/cmm, Differential leucocyte count- neutrophils-69/ cmm, lymphocytes-29/cmm, monocytes- $1 / \mathrm{cmm}$, eosinophils- $1 / \mathrm{cmm}$, basophils-0/cmm, Bleeding time-2minutes, Clotting time- 5minutes, Blood urea- 30mg\%, Blood glucose- 94mg\%. Pre anaesthetic check up was done and patient was accepted for anaesthesia.

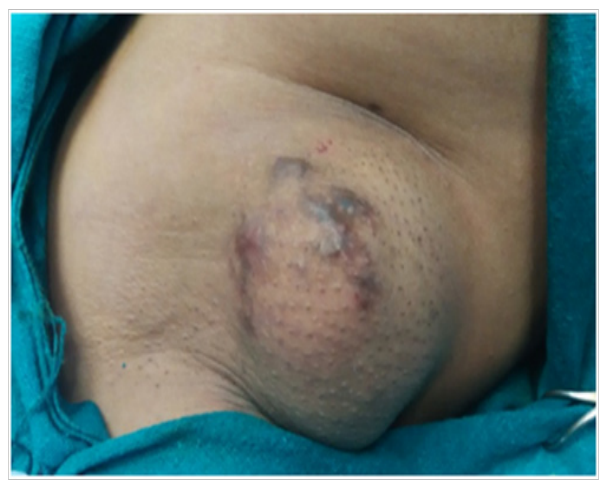

Figure I Preoperative photograph.

The patient was operated under general anaesthesia. Incision was given in skin and subcutaneous tissue. On undermining both flaps a solid mass started protruding from the incision (Figure 2). The size of this lump was $11 \mathrm{~cm} x 10 \mathrm{~cm}$ (Figure 3). Haemostasis was achieved using electrocautery. The excised specimen had a well defined capsule similar to fibroadenoma of breast (Figure 4). The cut surface of specimen had a whitish lobular appearance (Figure 5). The histopthological diagnosis was confirmed as fibroadenoma. Microphotographs show intracanalicular type of fibroadenoma having plenty of stroma (Figure 6). The postoperative period was uneventful and stitch line was healthy after stitch removal.

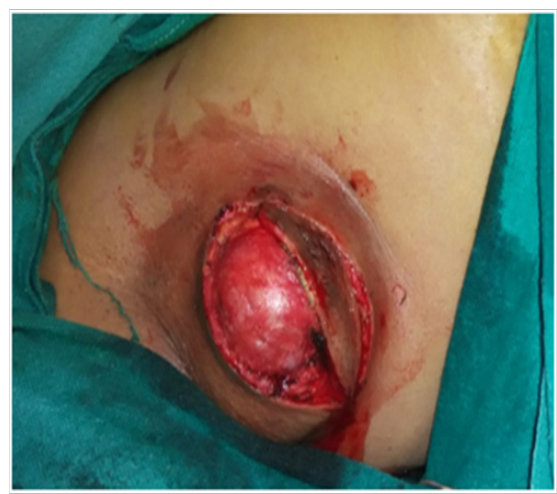

Figure 2 Peroperative photograph. 


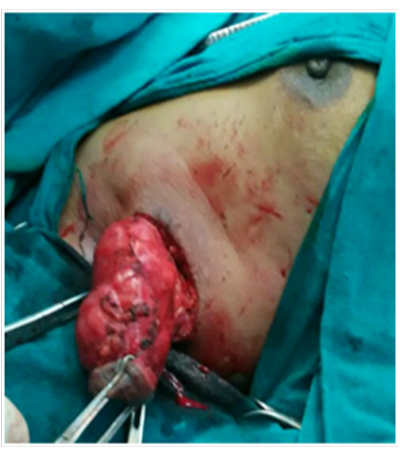

Figure 3 Giant Axillary Fibroadenoma being excised.

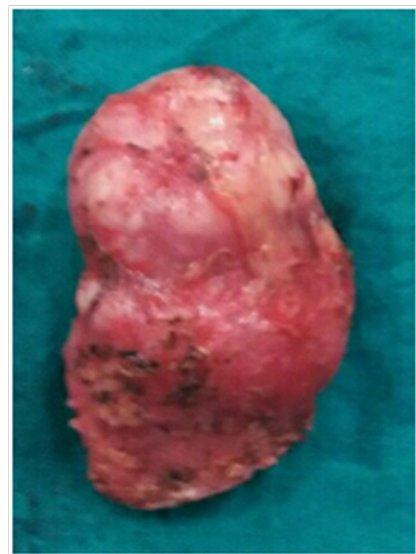

Figure 4 Excised Specimen well encapsulated.

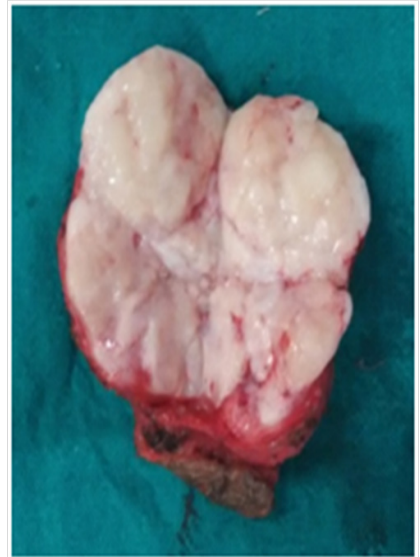

Figure 5 Specimen cut transversely.

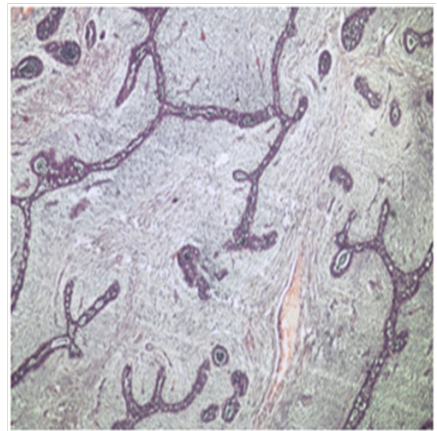

Figure 6 Microphotograph showing Intracanalicular Fibroadenoma

\section{Discussion}

The axillary ectopic breast tissue is part of polymastia present in milk line and presenting as axillary breast without nipple areola complex. The ectopic breast tissue is commonly present in axilla. This may not be palpable as swelling in axilla. But it becomes apparent during pregnancy and lactation. This ectopic axillary tissue is under hormonal influence like normal mammary glands. This axillary ectopic breast tissue can develop benign or malignant breast diseases similar to normal breast. ${ }^{9}$

These fibroadenoma can change the size. They can increase in size in about $5 \%$ of patients and regress in size in about $25 \%$ of patients with time [reference]. Bilateral fibroadenoma developing in both axillas have ectopic breast tissue have been reported. ${ }^{10,11}$ The origin of fibroadenoma has been attributed to ectopic breast tissue in axilla which may not be palpable clinically. Singh et al reported a case of right axillary fibroadenoma developing in a 28 years old woman. They observed that development of axillary fibroadenoma without presence of ectopic breast tissue and hormonal imbalance is a rare presentation. ${ }^{12}$ In this case a giant fibroadenoma developed without any history of swelling in the axilla even after lactation. Axillary fibroadenoma occur commonly in women between ages of 30 to 50years. It was observed that ultrasound and mammography are not useful as diagnostic technique. ${ }^{13}$ The age of this female patient was 38years in this case report. Ultrasonography of normal breast is diagnostic in making diagnosis of fibroadenoma but in case of fibroadenoma developing in ectopic axillary breast, the ultrasonography may not be diagnostic due to lack of mammary tissue around the mass.

Senatore et al. ${ }^{14}$ reported a 21years female having a solid nodular mass in axilla with a suspected diagnosis of axillary lymphadenopathy. In patients presenting as isolated swelling without inflammation or infection the diagnosis is difficult however lymphoma may be suspected in these cases. The histopathology of the mass removed confirmed the diagnosis of fibroadenoma. ${ }^{14}$ Surd A et al described a rare case of fibroadenoma in an accessory breast in a young woman. There are less than 40 case reports in literature. The differential diagnosis includes carcinoma developing in axillary breast, hidradenitis, lymphadenopathy, lipoma and phylooid tumour. A combined approach with clinical examination, ultrasound and cytology is helpful in making of diagnosis. Fine needle aspiration cytology can give suspicious findings, although having high sensitivity and low specificity can lead to false positive results. ${ }^{15}$ If clinical examination of axillary ectopic breast tissue is doubtful, the lesion should be investigated ultrasonography, mammography, fine needle aspiration cytology should be done as in other breast lesions. ${ }^{16}$

It is important to make a preoperative diagnosis so that definite treatment can be planned. All the fibroadenoma do not need excision. There is no strict size criterion for excision but breast fibroadenoma of larger size should be excised. Greenberg et al reviewed the management of fibroadenoma of breast and recommended conservative treatment with follow up in breast fibroadenoma in young females as the incidence of transformation to carcinoma is low. On the other side recommended excision for giant fibroadenoma of the breast. Giant fibroadenoma tend to decrease in size on cessation of lactation. The excision giant fibroadenoma in lactating woman should be delayed till weaning and hormone status returns to normal. As the fibroadenoma shrinks in size the excision can be carried out through a smaller incision. ${ }^{17}$ Giant fibro adenoma of breast can produce asymmetry of 
breast. Excision which is the recommended treatment can produce deformity of breast. Excision of giant fibroadenoma can be done using an inframammary or periareolar incision without reconstructive plasty should produce good aesthetic results. ${ }^{18}$ Excision is the favored surgical treatment for giant fibroadenoma of axilla. In this case also excision of fibroadenoma was done with good cosmetic result and outcome on follow up.

In summary, a thirty eight years female presented with a large swelling in right axilla for last two years. The last delivery and lactation was 14years back. She did not give history of any swelling appearing during last pregnancy and lactation. The swelling has appeared insidiously and grown to the present size over a period of two years. This swelling was painless but was interfering while wearing the clothes. She has approached the surgeon because of the fear of malignancy. She was diagnosed as having accessory axillary breast on clinical and ultrasound examination. But fine needle aspiration cytology diagnosed it as benign proliferative disorder. This large size swelling was excised and was a solid benign tumour confirmed on histopathological examination as fibroadenoma. Our findings match with various reports in surgical literature.

\section{Conclusion}

Breast fibroadenoma is the most common benign tumour in the normal breasts. The presence ectopic breast tissue in axilla is also common in women. But the development of fibroadenoma in axillary ectopic breast tissue is uncommon. The development of large fibroadenoma having size of more than $5 \mathrm{~cm}$ is very rare. In this case report giant fibro adenoma $11 \times 10 \mathrm{~cm}$ in right axilla was excised. There was no history of palpable ectopic breast tissue in right axilla in after lactation. Clinical profile, operative and pathological images are included in this case report.

\section{Acknowledgements}

None.

\section{Conflict of interest}

The author declares no conflict of interest.

\section{References}

1. Heilmann T, Leuschner I, Hilpert F, et al. Diagnosis and management of an unilateral giant fibroadenoma of the breast in pregnancy. Arch Gynecol Obstet. 2012;285(1):235-237.

2. Azoz MEH, Abdalla AE, Elhassan MM. Fibroadenoma in ectopic breast tissue:a case report. Sudan Med J. 2014;50(2):112-115.
3. Arora BK, Arora R, Arora. Axillary accessory breast: presentation and treatment. Int Surg J. 2016;3(4):2050-2053.

4. Ciralik H, Bulbuloglu E, Ozer A, et al. Fibroadenoma of the ectopic breast of the axilla-a case report. Pol J Pathol. 2006;57(4):209-211.

5. Singh S, Yadav H, Srivastava D, et al. A rare finding of coexisting fibroadenoma and duct ectasia in axillary ectopic breast tissue. $J$ Interdiscipl Histopathol. 2015;3(3):110-112.

6. Mukhopadhyay M, Saha AK, Sarkar A. Fibroadenoma of the ectopic breast of the axilla. Indian J Surg. 2010;72(2):143-145.

7. Kohli S, Garg P, Kharkwal S, et al. Rare clinical entitiy-Fibroadenoma of ectopic breast tissue. Indian J Basic and Applied Med Res. 2015;5(1):575-578.

8. Seo BF, Park SW, Oh DY. Giant fibroadenoma in the axilla: A common entity of uncommon size in a rare location. Arch Plast Surg. 2015;42(6):793-795.

9. Goyal S, Bawa R, Sangwan S, et al. Fibro adenoma of axillary ectopic breast tissue: A rare clinical entity. Clin cancer Investig J. 2014;3:242244.

10. Gentile P, Izzo V, Cervelli V. Fibroadenoma in the bilateral accessory axillary breast. Aesthetic Plast Surg. 2010;34:657-659.

11. Rajkumar B, Anbarasu S, Rajagopal L. Bilateral fibroadenoma of the ectopic breast tissue in axilla. Int J Med Sci Public Health. 2015;4:138-141.

12. Singh S, Bhargava A. Axillary fibroadenoma:case report and review of literature. Saudi J Med Med Sci. 2014;2:207-209.

13. Ortiz-Mendoza CM. Axillary ectopic breast tissue fibroadenoma:report of three cases and review of literature. Ginecol Obstet Mex 2012;80(2):99-103.

14. Senatore G, Zanotti S, Cambrini P, et al. Ectopic breast fibroadenoma. Case report. G Chir. 2010;31(3):96-99.

15. Surd A, Muresan R, Gocan H. Fibroadenoma in axillary supernumerary breast in a 17 years old girl: case report. J Preg Child Health 2015;2(5):79-81.

16. Swarnagowari BN, Suba G. Mouse in the axilla - Fibroadenoma of the accessory axillary breast tissue:A cytological diagnosis. Sch J Med Case Rep. 2013;1(2):30-31.

17. Greenberg R, Skomick Y, Kaplan O. Management of breast fibroadenomas. J Gen Intern Med. 1998;13(9):640-645.

18. Hille-Betz U, Klapdor R, Henseler H, et al. Treatment of giant fibroadenoma in young woman after toumor excision without reconstructive surgery. Geburtshilfe Frauenheikd. 2015;75(9):929-934. 